\title{
Eelgrass Zostera marina populations in northern Norwegian fjords are genetically isolated and diverse
}

\author{
Jeanine L. Olsen ${ }^{1, *}$, James A. Coyer ${ }^{2}$, Wytze T. Stam ${ }^{1}$, Frithjof E. Moy ${ }^{3}$, \\ Hartvig Christie $^{4}$, Nina Mari Jørgensen ${ }^{5}$ \\ ${ }^{1}$ Marine Benthic Ecology \& Evolution Group, Centre for Ecological and Evolutionary Studies, University of Groningen, \\ Nijenborg 7, 9747 AG Groningen, The Netherlands \\ ${ }^{2}$ Shoals Marine Laboratory, Cornell University, 400 Little Harbor Rd., Portsmouth, New Hampshire 03801, USA \\ ${ }^{3}$ Institute of Marine Research, Research Station Flødevigen, 4817 His, Norway \\ ${ }^{4}$ Norwegian Institute for Water Research, NIVA, Gaustadallen 21, 0349 Oslo, Norway \\ ${ }^{5}$ Akvaplan-NIVA, Fram Centre, 9296 Tromsø, Norway
}

\begin{abstract}
Populations along the northern boundary of a marine species' distributional range in the NE Atlantic are expected to harbor lower standing genetic variation as a consequence of postglacial expansion following the last glacial maximum. Founder events and marginal habitat availability may render the edge populations more vulnerable to anthropogenic stress and less capable of rapid adaptation to global climate change, a concern for conservation and management. We analyzed meadow architecture, persistence and connectivity within and among 15 locations (600 samples genotyped with 8 microsatellite loci) in 3 fjords in Troms County, Norway $\left(69^{\circ} \mathrm{N}\right)$. Whereas global mean allelic diversity (standardized for sample size) was in accordance with previous studies using the same markers, more extensive sampling revealed a broader range of allelic richness (mean $=2.85$; range $=1.84$ to 4.21 ) in the regional pool. Genotypic diversity was typically high, whereas large genets were rare (2 out of 15 locations). Population differentiation $\left(F_{\mathrm{ST}}\right)$ was 2 to 6 times higher between fjords than within fjords. A Bayesian (STRUCTURE) analysis also strongly supported the genetic distinctness of each fjord. Although 9 locations within the $60 \mathrm{~km}$ long Balsfjord were connected by gene flow, demographic connectivity may actually be low, as fixed differences were observed at 6 of the 9 locations, along with significantly positive inbreeding coefficients and strong substructure. Overall, our results suggest that these northern, leading-edge meadows are healthy, but vigilance is required to avoid further losses. Fjord-level management, especially of the larger fjords, will be sufficient to capture the range of variation.
\end{abstract}

KEY WORDS: Seagrass · Zostera marina - Populations · Genetic diversity · Management • Leading-edge Resale or republication not permitted without written consent of the publishe

\section{INTRODUCTION}

Seagrass meadows provide foundational habitat by supporting high biodiversity (Hughes \& Stachowicz 2004, Waycott et al. 2006) and numerous ecosystem services, ranging from erosion protection and carbon sequestration to nursery functions and recreation (Costanza et al. 1997, Heck et al. 2003, Joseph et al. 2006). Unfortunately, seagrasses are suffering a global decline due to a variety of changes related either indirectly (through climate change) or directly (as a consequence of habitat destruction, reduced water 
quality, physical disturbance from commercial fishing, aquaculture and invasive species) to anthropogenic activities (Orth et al. 2006, Waycott et al. 2009).

Eelgrass Zostera marina L. is the most widely distributed seagrass in temperate, northern hemisphere regions of both the Pacific and Atlantic Oceans. It is the dominant seagrass along European shores, ranging from northern Norway to southern Portugal. Along the Norwegian coast, eelgrass has been considered relatively common in the south, but progressively scattered and less abundant in the northernmost areas, as a consequence of habitat limitation (Lid \& Lid 1994). However, a mapping project initiated in 2007 under the National Program for Mapping and Monitoring of Marine Biodiversity (Bekkby et al. 2008, 2011) has revealed a more extensive distribution in the higher latitudes than expected, recording $>3000$ beds ranging in size from $100 \mathrm{~m}^{2}$ to $6 \mathrm{~km}^{2}$. Consequently, the Norwegian Directorate for Nature Management (www.naturbase.no) and Akvaplan-NIVA (www.akvaplan.niva.no) have initiated an action plan to establish legislation through the Nature Diversity Act of 19 June 2009 that will ensure sustainability of and promote basic research on seagrass habitat.

Although Zostera marina has been recorded in northern Norway since the 1880s (Norman 1900), very little research has been conducted on the biology or ecology of eelgrass itself or its role in community dynamics. Duarte et al. (2002) found no limitation on growth rate associated with nutrients, irradiance or day length, while working in Hopavagen Lagoon $\left(63^{\circ} 35^{\prime} \mathrm{N}, 9^{\circ} 32^{\prime} \mathrm{E}\right)$, suggesting that long term persistence was not physiologically limited. The only other studies we are aware of were performed in southern Norway and focused on epiphytes, epifauna, infauna and grazing effects on eelgrass (Fredriksen \& Christie 2003, Fredriksen et al. 2004, 2005,2010 ). It should also be noted that, although our study area lies well above the Arctic Circle $\left(68^{\circ}\right.$ to $70^{\circ} \mathrm{N}$ ), it is considered sub-Arctic from a biogeographic perspective, based on the influence of the Gulf Stream and the $10^{\circ} \mathrm{C}$ July isotherm, which skirts just north of the country (Stonehouse 1989, www. amap.no). This suggests that suitable habitat and temperatures supportive of larger and possibly higher diversity populations than predicted have been present for many thousands of years.

Recolonization of Zostera marina throughout the NE Atlantic commenced at the end of the last glacial maximum (LGM) (18 000 yr BP) (Bradwell et al. 2008) from more southerly refugia in parts of Ireland, the Brittany peninsula of western France and northern
Spain (Olsen et al. 2004, Becheler et al. 2010). Northerly refugia in Iceland and the Lofotan peninsula of Norway have also been proposed (see Maggs et al. 2008, Coyer et al. 2011). As the glaciers retreated, northerly expansion ensued via 'leadingedge' populations (Ibrahim et al. 1996), derived from the refugial pool(s). Leading-edge populations are expected to exhibit lower allelic diversity (reviewed in Hewitt 2004) as a consequence of founder effects and small population sizes that are strongly affected by genetic drift. Many benthic marine species present this phylogeographic gradient of 'southern richness and northern purity' (Hewitt 2004, Maggs et al. 2008).

Knowledge of population genetic structure in seagrasses provides inferences about meadow architecture and ecological processes related to meadow dynamics, as well as growth and persistence through sexual reproduction and vegetative spread of genets to produce large clones (Waycott et al. 2006, Procaccini et al. 2007). Meadows may be heterogeneous as a consequence of temporal admixture events of repeated recruitment through time (originally proposed by Petit et al. 2003 for oaks, Becheler et al. 2010); limited dispersal of pollen and seeds, leading to patchiness (Hämmerli \& Reusch 2003); and local habitat selection (Oetjen \& Reusch 2007, Oetjen et al. 2010, Winters et al. 2011). Alternatively, they can be homogeneous as a consequence of dominance by a few large genets/clones (Reusch et al. 1999, Coyer et al. 2008) and limited recruitment (Duarte et al. 2006).

Isolation of meadows further affects the maintenance of diversity, especially if populations are small and dispersal is limited (Waycott et al. 2006, Procaccini et al. 2007). The complexity of the Norwegian coastal fjord system creates vast amounts of dissected and patchy habitat, which conceivably could enhance or reduce diversity and gene flow within the regional pool, depending on local currents and physical barriers. Since, from a conservation perspective, the overall effect of reduced genetic variation is a reduction in adaptive potential, it is necessary to determine whether fjord populations in the high latitudes may be exceptionally vulnerable.

In the present study we focus on northern fjord populations $\left(68^{\circ}\right.$ to $\left.70^{\circ} \mathrm{N}\right)$ in Troms County, Norway. Our aims were to (1) test, via more extensive sampling, the degree to which northern fjord populations conform to the predicted low allelic diversity profile associated with the leading-edge hypothesis, (2) assess the relative contributions of sexual reproduction and the vegetative spread of large genets/clones to meadow architecture as an indicator of long-term 
persistence, (3) test the level of population differentiation and isolation as an indicator of connectivity within and between fjords and (4) identify whether ecotypes (e.g. Zostera marina var. angustifolia) are specific to subtidal or intertidal habitats.

\section{MATERIALS AND METHODS}

\section{Sample collection and DNA extraction}

Samples ( $\mathrm{n}=50$ per location) of Zostera marina were collected from 15 locations in 3 fjords: Balsfjord $(\mathrm{n}=9)$, Sør-Lenangen (2) and Sagfjord in Salangen (4) (Fig. 1, Table 1). Samples were collected both by wading and diving (tidal difference in the area $\sim 3 \mathrm{~m}$ ), at 1 to 1.5-m intervals in which direction was determined by a random walk. The only exceptions to this sampling strategy were the Laksvatn samples in Balsfjord. These were collected along 3 transects (high, medium, low intertidal), which ran parallel to the shore. Leaves from individual shoots (ramets) were cut into two or

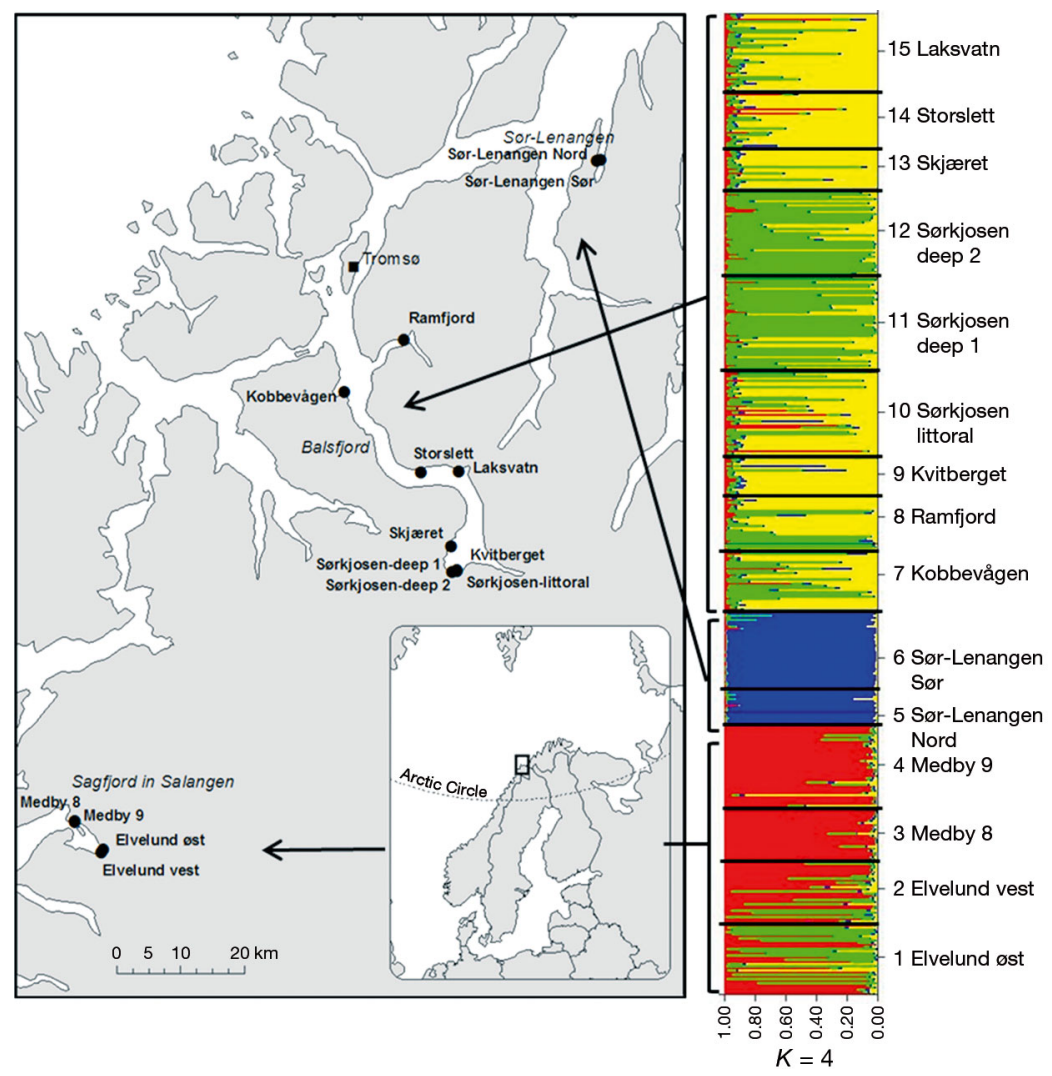

Fig. 1. Location of sampling sites for Zostera marina including the results of the STRUCTURE analysis (Pritchard et al. 2000). Each individual is represented by a horizontal bar partitioned into colored segments, the length of which is proportional to the individual's membership in each of 4 clusters $(K=4)$. See 'Materials and methods: Data analysis' for determination of $K$ three $2 \mathrm{~cm}$ pieces, blotted dry and placed into tubes with silica crystals for dehydration and preservation. Leaf tissue was pulverized in the laboratory, using an MM 301 mixer mill (Retsch). DNA was extracted using a silica-based method as described by Hoarau et al. (2007) and Coyer et al. (2009), except that the cetyl trimethylammonium bromide (CTAB)/sample slurry was heated at $60^{\circ} \mathrm{C}$ for $1 \mathrm{~h}$.

\section{Microsatellite amplification and genotyping}

Template DNA for polymerase chain reactions was obtained from $1 \mu \mathrm{l}$ of the final DNA solution (typically 2 to $10 \mathrm{ng}$ ). Eight species-specific microsatellite loci were multiplexed (CT2, CT23, CT35, CT12, CT16, CT17D, CT19, CT20) for PCR amplification (Reusch 2000, Reusch et al. 2000). A recent study of Zostera marina revealed that 2 loci commonly used (CT17H and CT35) sometimes revealed signs of genetic mosaicism (somatic mutation producing $>2$ alleles per ramet) among populations at the northern and southern limit of its European distribution (Reusch \& Boström 2011). The complexity of the microsatellite genotypes suggested that there were one or more divergent cell lineages present within a single ramet. In the present study, complex genotypes were found for $\mathrm{CT} 17 \mathrm{H}$ and this locus was eliminated, whereas CT35 displayed biallelic patterns for the 14 alleles and was retained. Genotypes were visualized on an ABI 3730 gene analyser (Applied Biosystems) and analysed using GENOTYPER (Applied Biosystems) software.

\section{Data analysis}

A genetic individual (genet) consists of many shoots (ramets), which can extend for several meters. Large genets are referred to as clones (see Procaccini et al. 2007 for discussion of terminology). Thus, sampled shoots in an area can have the same multilocus genotype (MLG) if part of the same large clone. The number of genets and ramets sampled in a given area were distinguished with GenClONE 2.0 (Arnaud-Haond \& Belkhir 2007). Prob- 
Table 1. Zostera marina. Collection sites and general information. Sampling dates are given as dd/mm/yyyy

\begin{tabular}{|c|c|c|c|c|}
\hline $\begin{array}{l}\text { Fjord region } \\
\text { Name of location }\end{array}$ & $\begin{array}{l}\text { Location } \\
\text { description }\end{array}$ & $\begin{array}{l}\text { Date of } \\
\text { sampling }\end{array}$ & $\begin{array}{l}\text { Coordinates } \\
(\mathrm{N}, \mathrm{E})\end{array}$ & $\begin{array}{l}\text { Collection } \\
\text { depth (m) }\end{array}$ \\
\hline \multicolumn{5}{|l|}{ Sagfjord } \\
\hline Elvelund-øst & River outlet, sand, subtidal & $17 / 06 / 2011$ & $68^{\circ} 51.93^{\prime}, 17^{\circ} 49.85^{\prime}$ & 0.4 \\
\hline Elvelund-vest & River outlet, sand, subtidal & $17 / 06 / 2011$ & $68^{\circ} 52.20^{\prime}, 17^{\circ} 50.28^{\prime}$ & 0.4 \\
\hline Medby WP8 & Tidal flat, mud, subtidal & 18/06/2011 & $68^{\circ} 54.58^{\prime}, 17^{\circ} 43.95^{\prime}$ & 0.5 \\
\hline Medby WP9 & Tidal flat, mud, subtidal & 18/06/2011 & $68^{\circ} 54.60^{\prime}, 17^{\circ} 43.98^{\prime}$ & 0.5 \\
\hline \multicolumn{5}{|l|}{ Sør-Lenangen } \\
\hline Sør-Lenangen Nord & Tidal flat, river outlet $2 \mathrm{~km}$ away, mud, intertidal & $21 / 06 / 2011$ & $69^{\circ} 47.42^{\prime}, 19^{\circ} 59.39^{\prime}$ & 0.3 \\
\hline Sør-Lenangen Sør & Tidal flat, river outlet $2 \mathrm{~km}$ away, mud, intertidal & $21 / 06 / 2011$ & $69^{\circ} 47.35^{\prime}, 19^{\circ} 58.39^{\prime}$ & 0.3 \\
\hline \multicolumn{5}{|l|}{ Balsfjord } \\
\hline Kobbevågen & Tidal flat (RAMSAR site), mud & $16 / 08 / 2011$ & $69^{\circ} 29.54^{\prime}, 18^{\circ} 53.47^{\prime}$ & 2 \\
\hline Ramfjord & Tidal flat, soft, mixed sand/mud & $16 / 08 / 2011$ & $69^{\circ} 33.56^{\prime}, 19^{\circ} 08.44^{\prime}$ & 1.5 \\
\hline Kvitberget & Tidal flat, soft, mixed sand/mud & $17 / 08 / 2011$ & $69^{\circ} 13.92^{\prime}, 19^{\circ} 17.42^{\prime}$ & 0.3 \\
\hline Sørkjosen-littoral & Tidal flat (RAMSAR site), mud & $17 / 08 / 2011$ & $69^{\circ} 13.83^{\prime}, 19^{\circ} 17.47^{\prime}$ & 0.3 \\
\hline Sørkjosen-deep 1 & Tidal flat (RAMSAR site), mud & $17 / 08 / 2011$ & $69^{\circ} 13.86^{\prime}, 19^{\circ} 17.32^{\prime}$ & 2.5 \\
\hline Sørkjosen-deep 2 & Tidal flat (RAMSAR site), mud & $17 / 08 / 2011$ & $69^{\circ} 13.76^{\prime}, 19^{\circ} 16.13^{\prime}$ & $4-5$ \\
\hline Skjæret & Shallow, soft, mixed sand/mud & $17 / 08 / 2011$ & $69^{\circ} 15.96^{\prime}, 19^{\circ} 16.32^{\prime}$ & 3 \\
\hline Storslett & Tidal flat, very muddy & 18/08/2011 & $69^{\circ} 22.36^{\prime}, 19^{\circ} 10.34^{\prime}$ & 0.3 \\
\hline Laksvatn & Tidal flat, soft, mixed sand/mud & $18 / 08 / 2011$ & $69^{\circ} 22.18^{\prime}, 19^{\circ} 19.38^{\prime}$ & $0-1$ \\
\hline
\end{tabular}

abilities of identity by chance $\left(P\right.$ sex $\left.\left(F_{\text {IS }}\right)\right)$ were calculated for each sample to avoid false assignment of individual ramets, sharing the same MLG by chance, to the same genet (clone). Psex $\left(F_{\mathrm{IS}}\right)$ accounts for departure from Hardy-Weinberg equilibrium (HWE) and provides the most conservative estimates of clonal identity (Arnaud-Haond \& Belkhir 2007).

Genotypic diversity, $R$ (number of genets, G-1, over number of sampled ramets, $N-1$ ); and allelic richness, $A_{C}$ (number of alleles per locus), corrected for the minimum number of genets identified among all locations (here $\mathrm{n}=17$ ), were also calculated with GENClone 2.0. Expected heterozygosity $\left(H_{\mathrm{e}}\right)$ and Wright's fixation indices $\left(F_{\mathrm{IS}}\right.$ and $\left.F_{\mathrm{ST}}\right)$ were calculated using GenETIX 4.05 (Belkhir et al. 2001). All subsequent analyses of population structure used unique genets only, i.e. duplicate MLGs were removed.

Linkage disequilibrium (LD) was assessed in ARLEQUIN 3.5 (Excoffier et al. 2005). Pairwise comparisons of all loci $(n=8)$ per population $(n=15)$ were compared using a likelihood ratio test (Slatkin \& Excoffier 1996) and tested for significance $(p=0.05)$ with 10000 permutations.

Clone size was estimated based on the spatial resolution of the linear sampling method (i.e. 1 to $1.5 \mathrm{~m}$ ), which provided a coarse minimum value only; shoots were not sampled in a grid or mapped. For example, if 3 consecutive samples had the same MLG, the clone was estimated as minimally 3 to $4.5 \mathrm{~m}$ in size.
Population structure was first analyzed in a classic $F_{\mathrm{ST}}$-based format, using genetic distances based on the Cavalli-Sforza and Edwards chord distance and neighbor-joining, using the software package PHYLIP 3.5 (Felsenstein 1994). We used GENDIST for computing genetic distances, NEIGHBOR for constructing the tree, CONSENCE for constructing the consensus tree and SEQBOOT for the bootstrap resampling.

Isolation by distance (IBD) (Wright 1943, Slatkin 1993) was evaluated by correlating estimates of $F_{\mathrm{ST}}$ / $1-F_{\mathrm{ST}}$ (Rousset 1997), using the $\theta$ estimator (Weir \& Cockerham 1984), with geographic distances. This was done using matrix correlation methods based on the Mantel test (Manly 1994) and 10000 randomizations with IBD Web Service v.3.23 (Jensen et al. 2005). Linear distances were determined with waypoints taken in the field and ArcGIS. Geographic distances $(\mathrm{km})$ were log-transformed in accordance with a 2-dimensional stepping stone model, which we deemed more appropriate, given the dissected nature of the fjord system.

Population structure was also analyzed in a Bayesian framework implemented in the software StRuCture 2.3.3 (Pritchard et al. 2000). In this approach there is no a priori designation of 'populations'. The admixture model was used to estimate the log probability $P(X \mid K)$ of encountering each userdetermined set of clusters/populations $(K=2,3,4$, etc.), by genetic assignment of individuals to the most 
Table 1. (continued)

\begin{tabular}{|c|c|c|}
\hline $\begin{array}{l}\text { Water } \\
\text { temp. }\left({ }^{\circ} \mathrm{C}\right)\end{array}$ & $\begin{array}{l}\text { Sample } \\
\text { numbers }\end{array}$ & Additional observations \\
\hline $5-7$ & $0-49$ & Patchy distribution. Plant length max. $20-25 \mathrm{~cm}$. \\
\hline $5-7$ & $50-99$ & Patchy distribution. Plant length max. $20-25 \mathrm{~cm}$. \\
\hline $5-7$ & $100-149$ & Large, dense meadow. Plant length max. $20-25 \mathrm{~cm}$. \\
\hline $5-7$ & $150-199$ & Large, dense meadow. Plant length max. $20-25 \mathrm{~cm}$. \\
\hline $5-7$ & $200-249$ & Small patches. Plant length max. $15 \mathrm{~cm}$. \\
\hline $5-7$ & $250-299$ & Small patches. Plant length max. $15 \mathrm{~cm}$. \\
\hline 11 & $300-349$ & Small, dense, subtidal meadow. Plant length max. 25-40 cm. Diving. \\
\hline 11 & $350-399$ & Small subtidal meadow. Patchy plant distribution. Plant length max. $25 \mathrm{~cm}$. Diving. \\
\hline 9 & $400-449$ & Sparse but continuous intertidal meadow. Small Z. marina var. angustifolia type morphology. \\
\hline 9 & $450-499$ & Moderately dense, intertidal meadow. Small $Z$. marina var. angustifolia type morphology. \\
\hline 9 & $500-549$ & $\begin{array}{l}\text { Large, dense, subtidal meadow. Plant length max. } 89 \mathrm{~cm} . \\
\text { Flowers and seed capsules observed. Diving. }\end{array}$ \\
\hline 9 & $550-599$ & Large, subtidal meadow, $\sim 700 \mathrm{~m}$ from littoral. Flowers and seed capsules observed. Diving. \\
\hline 9 & $600-649$ & Subtidal meadow. Large but sparse patches of plants. Diving. \\
\hline 9 & $650-699$ & Large, intertidal meadow. Sparse patches of brown and unhealthy looking plants. \\
\hline 9 & $700-747$ & $\begin{array}{l}\text { Dense meadow. Sampling from } 3 \text { zones; shallow }-0 \mathrm{~m}(700-715) \text {, intermediate }-0.5 \mathrm{~m}(717-732) \text {, } \\
\text { deep }-1 \mathrm{~m}(734-749) \text {. Healthy looking plants. }\end{array}$ \\
\hline
\end{tabular}

likely clusters (see Fig. S1 in the Supplement at www.int-res.com/articles/suppl/m486p121_supp.pdf). The true number of clusters was estimated under 2 assumption sets using the web-based STRUCTURE HARVESTER (Earl \& vonHoldt 2012). In the first analysis, posterior probabilities for a given $K, P(X \mid K)$ (Pritchard et al. 2000), were determined directly, whereas in the second analysis the ad hoc statistic $\Delta K$ (Evanno et al. 2005) was used. The latter is recommended when asymmetrical dispersal patterns exist among given locations. The $\Delta K$ method is based on the rate of change of $P(X \mid K)$ values between different $K$, with the number of sampling locations used as priors and assigned to the most likely $K$. Each analysis was repeated 5 times $\left(10^{6}\right.$ iterations; burn-in = $100000)$ to avoid dependence on starting values.

\section{RESULTS}

Mean allelic richness $(\hat{A})$, a measure of genetic variation that was adjusted for a sample size of 17 , was 2.85 with a range of 1.82 to 4.21 (Table 2). Richness values varied between locations within all 3 fjords and were uncorrelated with substrate (sand or muddy) or depth (shore or subtidal position). Highest allelic richness was recorded at Elvelund-øst $(\hat{A}=$ $4.00)$ in the Sagfjord and the 2 Sørkjosen-deep sites ( $\hat{A}=4.05$ and 4.21) situated inside a Ramsar wetland site at the head of Balsfjord. The lowest values were found at Medby WP9 $(\hat{A}=1.82)$, Kvitberget $(\hat{A}=1.84)$ and Skjæret $(\hat{A}=1.98)$ in Balsfjord. Nine of the 15 locations sampled had putative private alleles $($ mean $=3.60 ;$ range $=1$ to 8$)$ and 10 locations showed at least 1 fixed allele (Sør-Lenangen had 5.) (Table 2).

Genotypic diversity $(R)$, a measure of clonality via vegetative spread of genets, was also highly variable, ranging from 0.319 at Sør-Lenangen Nord, where 3 large clones dominated, to 1.0 at Sørkjosendeep 1 and 2, and Ramfjord, where every shoot sampled belonged to a unique genotype (Table 2). Genotypic diversity was high $(R=0.872$ to 0.935$)$ at Sagfjord, while at Sør-Lenangen, 1 meadow consisted of 3 large clones extending to $21 \mathrm{~m}$ in size. Most genets, however, ranged minimally from 2 to $5 \mathrm{~m}$ in size, depending on the resolution of the sampling. Genotypic/clonal diversity was mostly high at Balsfjord, with a mix of moderately sized clones and many smaller ones at most locations. The highest allelic and genotypic diversities $(\hat{A}=4.21 ; R=1.00)$ were observed subtidally at the Sørkjosen Ramsar site, which hosts a large intertidal-subtidal meadow system of $>400000 \mathrm{~m}^{2}$, whereas the contiguous intertidal site was less allelically diverse with slightly more clones $(\hat{A}=2.58 ; R=0.957)$. The largest clones were at Sør-Lenangen Nord, which is near a river outlet. No genets were shared among the locations sampled. 
Table 2. Zostera marina. Genetic diversity and clonality, based on 8 microsatellite loci. $N=$ number of shoots analyzed, $G=$ number of genets, $R=$ genotypic diversity $(G-1 / N-1), \hat{A}=$ allelic richness (standardized to 17 genets), $p p=$ putatively private alleles found only at that location, fixed = number of fixed alleles (frequency $>0.97$ ), $G>1=$ number of genets with $>1$ ramet, $\mathrm{nR}=$ mean number of ramets per genet (distribution of duplicate ramets per genet given in brackets), $H_{\mathrm{e}}=$ expected heterozygosity, $F_{\mathrm{IS}}=$ Wright's fixation index estimated as $f$ (Weir \& Cockerham 1984, ${ }^{*} \mathrm{p}<0.05$ ), LD = linkage disequilibrium, i.e. proportion of pairwise comparisons that were significantly linked

\begin{tabular}{|c|c|c|c|c|c|c|c|c|c|c|c|}
\hline Location & $N$ & $G$ & $R$ & $\hat{A}$ & $p p$ & fixed & $G>1$ & $\mathrm{nR}$ & $H_{\mathrm{e}}$ & $F_{\text {IS }}$ & LD \\
\hline Elvelund-øst & 29 & 27 & 0.93 & 4.00 & 8 & 0 & 2 & 2 & 0.443 & $0.157^{*}$ & 0.64 \\
\hline Elvelund-vest & 40 & 35 & 0.87 & 3.04 & 4 & 0 & 3 & $1.8(2,3,4)$ & 0.342 & 0.069 & 0.36 \\
\hline Medby WP8 & 48 & 42 & 0.87 & 2.12 & 0 & 3 & 2 & $4(2,6)$ & 0.214 & -0.171 & 0.00 \\
\hline Medby WP9 & 47 & 44 & 0.93 & 1.82 & 2 & 3 & 1 & 4 & 0.248 & -0.041 & 0.07 \\
\hline Sør-Lenangen Nord & 48 & 16 & 0.31 & - & 0 & 5 & 3 & $11.7(3,15,17)$ & 0.183 & 0.101 & 0.00 \\
\hline Sør-Lenangen Sør & 48 & 42 & 0.87 & 2.62 & 4 & 5 & 2 & $3(2,4)$ & 0.183 & -0.025 & 0.00 \\
\hline Kobbevågen & 35 & 34 & 0.97 & 2.75 & 4 & 2 & 1 & 2 & 0.273 & $0.167^{*}$ & 0.43 \\
\hline Ramfjord & 29 & 29 & 1.00 & 3.50 & 0 & 1 & 0 & - & 0.265 & $0.241^{*}$ & 0.28 \\
\hline Kvitberget & 47 & 46 & 0.97 & 1.84 & 4 & 3 & 1 & 2 & 0.202 & $0.315^{*}$ & 0.07 \\
\hline Sørkjosen-littoral & 48 & 46 & 0.95 & 2.58 & 0 & 0 & 2 & $2.5(2,3)$ & 0.264 & $0.221^{*}$ & 0.14 \\
\hline Sørkjosen-deep 1 & 41 & 41 & 1.00 & 4.21 & 3 & 0 & 0 & - & 0.430 & $0.215^{*}$ & 0.21 \\
\hline Sørkjosen-deep 2 & 41 & 41 & 1.00 & 4.05 & 2 & 0 & 0 & - & 0.387 & 0.100 & 0.00 \\
\hline Skjæret & 48 & 46 & 0.95 & 1.98 & 3 & 4 & 2 & 2 & 0.162 & 0.067 & 0.00 \\
\hline Storslett & 48 & 40 & 0.83 & 2.26 & 0 & 2 & 2 & $4(2,6)$ & 0.183 & -0.007 & 0.03 \\
\hline Laksvatn & 47 & 42 & 0.89 & 2.98 & 0 & 1 & 3 & $2.7(2,3,4)$ & 0.219 & 0.050 & 0.00 \\
\hline
\end{tabular}

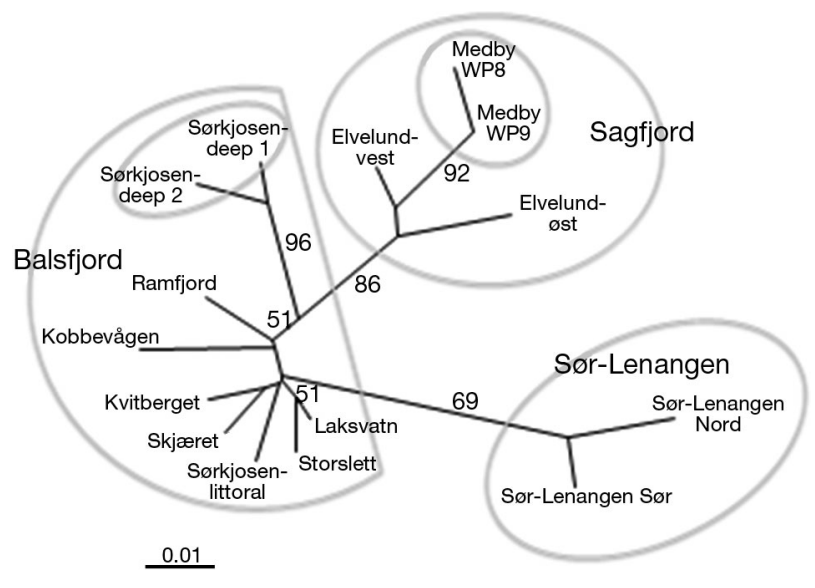

Fig. 2. Zostera marina. Relationships among populations in the study area of Troms County. The tree was based on pairwise Cavalli-Sforza and Edwards' chord distances (CavalliSforza \& Edwards 1967) between genets only. Bootstrap values were derived from 1000 resamplings

Mean $H_{\mathrm{e}}$ varied significantly, ranging from 0.162 at Skjæret to 0.430 at Sørkjosen-deep 1, sites separated by only $4 \mathrm{~km}$ (Table 2). Significant departures from HWE (6 locations) and linkage disequilibrium (LD) (7 locations) were observed (Table 2). Significantly positive values of $F_{\text {IS }}$ may be due to inbreeding and kinship (null alleles have seldom been encountered with these loci) or a possible Wahlund effect, although the latter explanation is not favored, given the sampling scale and strongly correlated LD (Table 2). Pairs of loci contributing to the LD within each population were not the same loci contributing to LD among

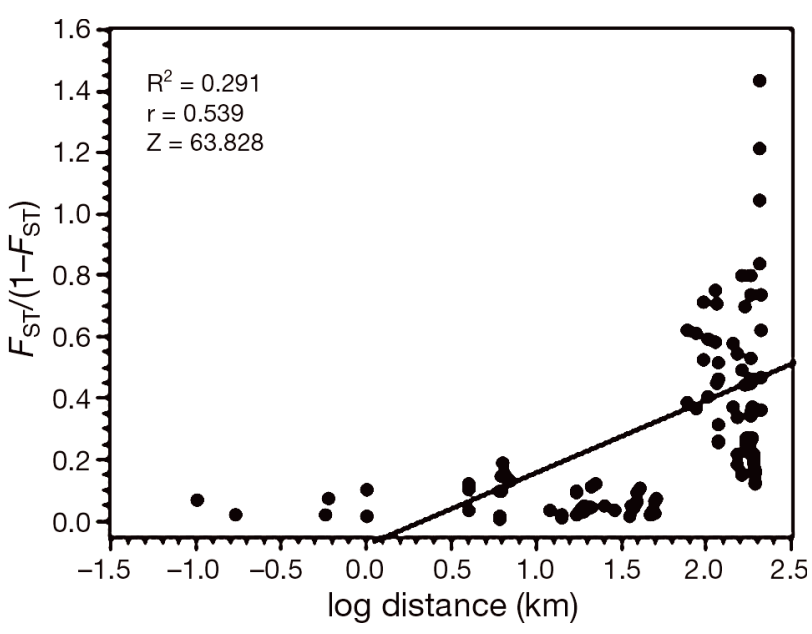

Fig. 3. Zostera marina. Isolation by distance (IBD). The genetic and geographic distance matrix (Table S1 in the Supplement) for $Z$. marina was compared with the Mantel Test and 10000 randomizations; the estimate of $R^{2}$ was calculated using reduced major axis (RMA) regression (Jensen et al. 2005) among all pairwise comparisons. Within-fjord distances ranged from 0.6 to $50 \mathrm{~km}$; between-fjord distances ranged from 77 to $208 \mathrm{~km}$

populations, and the number of loci involved was 1 or 2 . In contrast, the 2 Elvelund locations showed strong LD with 18 out of 28 comparisons significant at Elvelund-øst and 10 out of 28 significant at Elvelundvest. Significant LD, involving 2 pairs of loci (GA2 and GA12, and GA23 and GA17D), were matched between the 2 locations; all other comparisons involved different pairs of loci. 
Population differentiation $\left(F_{\mathrm{ST}}\right)$ was 2 to 6 times higher among fjords than within fjords (see Table S1 in the Supplement). The trend was further supported by 3 well-supported clusters in the neighbor-joining tree (Fig. 2). There was no true IBD among fjords, as the regression line in Fig. 3 reflects differences in spatial scaling of the sampling. Likewise, the Bayesian STRUCTURE analysis (Fig. 1) strongly separated each of the fjords with $K=3$ or $K=4$. Populations were also substructured within fjords, as almost all pairwise $F_{\mathrm{ST}}$ comparisons were significant $(\mathrm{p}<0.05)$ following Bonferroni correction and all but 4 were significant without Bonferroni correction (Table S1 in the Supplement).

There was no IBD within fjords (Fig. 3). Pairwise $F_{\mathrm{ST}}$ values ranged from 0.0921 to 0.1611 within Sagfjord. The significant values found for the Elvelund-østElvelund-vest, and Medby WP8-Medby WP9 pairs reflect geographic distances of $<1 \mathrm{~km}$, and within SørLenangen, significant differentiation $\left(F_{\mathrm{ST}}\right.$ value $=$ 0.0717 ) was found between 2 locations only, which were $0.6 \mathrm{~km}$ apart. Populations within the entire $60 \mathrm{~km}$ length of Balsfjord revealed a mean $F_{\mathrm{ST}}$ of 0.0536 (range $=0.0079$ to 0.1179 ), with Kobbevågen differing most. The 2 deep sites at Sørkjosen, within the Balsfjord, were comprised of many genotypes and formed a well-supported group in all analyses (Figs. 2 \& 3).

Small plants, morphologically attributable to Zostera marina var. angustifolia, were collected in the midhigh intertidal at Kvitberget and Sørkjosen-littoral. Both of these locations are close to, and/or contiguous with, the Sørkjosen-deep sites (Sørkjosen-littoral is $120 \mathrm{~m}$ from the deep sites and $6 \mathrm{~km}$ from Kvitberget). Microsatellite loci did not distinguish the 'angustifolia' morphotype from $Z$. marina (Fig. 3).

\section{DISCUSSION}

Scientists and conservation managers alike need to understand the determinants of seagrass health, specifically what affects persistence, sustainability, and extent (area and density). Although they only form one component of conservation and management, population genetic analyses provide evolutionary insights about both historical and contemporary processes that have shaped, and are likely to shape, future sustainability. These include a snapshot of relative recruitment, turnover and genetic potential, averaged over several generations, thus providing baseline information about potential vulnerability, past resistance and stability (Procaccini et al. 2007). Genetic characterization of population structure also provides partial (although incomplete) information about connectivity (Gaggiotti 2010) and ecological coherence that are relevant to marine spatial planning and protected area design (Nilsson-Jacobi \& Jonsson 2011, 2012). And finally, genetic surveys provide a practical guide for seagrass mitigation and restoration (Reynolds et al. 2012) by identifying allelic and clonal diversity. In short, the 'evol-eco' approach (Pennisi 2012) is gaining importance in both primary research and conservation management, because it is recognized that both occur in contemporary time (Spielman et al. 2004, Allendorf \& Luikart 2007).

\section{Past informs present}

Signatures of past climate change (such as relatively lower genetic diversity) remain visible in some northern populations of Zostera marina, as predicted by phylogeographic theory (Hewitt 2000). For example, mean values of allelic diversity in our study (mean $\hat{A}=$ 2.85 , range $=1.84$ to 4.21 , normalized to $\mathrm{n}=17,15$ locations, $200 \mathrm{~km}$ range) compared favorably with values from Iceland $\left(64^{\circ} \mathrm{N}\right.$, mean $\hat{A}=1.59$, range $=$ 1.51 to 1.64 , normalized to $\mathrm{n}=22,2$ locations, $50 \mathrm{~km}$ range) (Olsen et al. 2004) and southwestern Greenland $\left(64^{\circ} \mathrm{N}\right.$, mean $\hat{A}=2.20$, range $=1.38$ to 3.00 , normalized to $\mathrm{n}=10,4$ locations, $50 \mathrm{~km}$ range) (Diekmann \& Serrão 2012). The finding of a few locations with values of $\hat{A}>4$ (Table 2 ) are more typical of southerly locations such as western Sweden, the Skagerrak and the western Atlantic coast of America (Olsen et al. 2004, Diekmann \& Serrão 2012). Three non-mutually exclusive explanations may explain the diversity patterns. First, the higher diversity may have resulted in part from biased sampling in that global surveys generally assess diversity on a per population basis over the entire distributional range (Olsen et al. 2004), with most sampling occurring in the middle of the range (Diekmann \& Serrão 2012). Second, the highly dissected coastline of the Norwegian fjord system and large meadow sizes in some fjords, combined with strong population differentiation and evidence for sexual recruitment, rather than vegetative expansion (particularly in large, dense meadows such as Sørkjosen; see next subsection), may foster higher levels of diversity, as also observed in Brittany (Becheler et al. 2010). Finally, the higher diversity may be related to a cryptic refugium on the coastal island of Andøya (near Lofotan, Troms County), which has been suggested for both terrestrial and marine species (reviewed in Maggs et al. 2008, Coyer et al. 2011). We conclude that, while overall mean allelic di- 
versity is consistent with the leading edge hypothesis, pockets of higher diversity may ensure stability, as well as expansion further north (e.g. Jan Mayen, Eastern Spitzbergen) and east along the Siberian coast.

\section{Clonal diversity and population structure}

Understanding the genetic structure of populations provides insights into meadow dynamics, growth and persistence through sexual reproduction and vegetative spread. In our study, within-meadow allelic diversities varied widely and were roughly proportional to meadow size, whereas genet/clonal diversity was more uniform (Table 2). Our initial prediction for the Norwegian populations was low genotypic diversity (i.e. presence of a few large genets/clones), a characteristic of isolation and reduced sexual reproduction (Duarte et al. 2006) typically present in marginal populations such as those in the northern Baltic (Reusch et al. 1999), the Black Sea (Olsen et al. 2004) and the southern-most distribution in Portugal (Billingham et al. 2003). To the contrary, only 1 of the 15 sampled locations, an intertidal river outlet at Sør-Lenangen Nord with 5 fixed differences, was dominated by large genets/clones. $R$ values below 0.50 were mostly intertidal (4 out of 6 ) with the exception of the two Medby sites (Sagfjord) and Skjæret (Balsfjord). However, the remaining 9 locations in both Sagfjord and Balsfjord displayed $R$ values $>0.60$ with Sørkjosen-deep (Balsfjord) displaying maximal genet/clonal diversity (every shoot a different genet) and no fixed differences. In general, the larger, denser meadows had higher allelic diversity and were subtidal, whereas genet/clonal diversity was independent of meadow size or depth. The independence of genet/clonal diversity was unexpected, as subtidal populations were assumed to be protected from annual ice scour; nevertheless, the large Sør-Lenangen Nord genets/clones were in 0 to $30 \mathrm{~cm}$ of water. Although we have no direct measures of growth rate, the presence of small to medium sized genets/clones (2 to $4 \mathrm{~m}$ ) and an expansion rate of 10 $\mathrm{cm} \mathrm{yr}^{-1}$ in the Baltic (Reusch et al. 1994, 1999), suggests an age of 20 to $40 \mathrm{yr}$ in the fjords and thus, a slow turnover rate. The large genets/clones at SørLenangen Nord could therefore be considerably older.

Flowering was widespread from June to August, indicating the potential for new recruitment, which is less common in marginal habitats (Procaccini et al. 2007). However, the presence of fixed allelic differences at 10 of the 15 locations, and significant inbreeding coefficients at 6 locations (Table 2) suggest that individual meadows within a fjord were more isolated than indicated by gene flow (see next subsection). Although selfing occurs in Zostera marina, outcrossing remains the main reproductive strategy (Reusch 2001). Mating among relatives is common in relatively closed (dense) meadows (e.g. Z. noltii; Zipperle et al. 2009) and biparental inbreeding may or may not reduce fitness in $Z$. marina (Hämmerli \& Reusch 2003). In principle, a Wahlund effect could account for the positive $F_{\text {IS }}$ values at some locations, although this seems less likely given the spatial scale of the sampling. Instead, the correlation between positive $F_{\text {IS }}$ and strong LD (Table 2) at 6 locations is more consistent with non-random mating. With the exception of 3 comparisons between the 2 Elvelund populations, the loci contributing to the LD within each population were not the same loci contributing to LD among populations, which is consistent with population rather than physical linkage effects. This is also in agreement with the lack of significant results observed in Olsen et al. (2004) and the many other studies utilizing these loci.

Considering both allelic and genotypic diversity together, we conclude that present conditions for Zostera marina in the northern fjords are stable and that these meadows are not on the edge of local extinction as might be predicted based on distributional-edge assumptions. Strong inbreeding coefficients and LD suggest that selfing and mating with relatives may be unavoidable at some locations.

\section{Isolation or connectivity}

Significant population differentiation existed between fjords, typically 2 to 6 times higher than differentiation found within fjords (Table S1 in the Supplement, Figs. 1 \& 2). Consequently, fjords are strongly isolated from one another, whereas meadows within fjords may or may not be isolated. For example, the 2 Medby, 2 Elvelund, 2 Sør-Lenangen and 2 Sørkjosen locations are $<1 \mathrm{~km}$ apart and distinct, whereas Laksvatn, Skjæret and Storslett are 6 to $20 \mathrm{~km}$ apart and well-connected by gene flow. This uncertainty stems from the fact that the genetic results (gene flow) conflict with demographic inferences drawn from the genotypic diversity part of the analysis and both form part of population structure (Lowe \& Allendorf 2010). Simulation studies of dispersal distances of Zostera marina suggest that $50 \%$ of the floating rhiphidia stay within $500 \mathrm{~m}$, with a highly skewed tail of long distance dispersal over a few km (Källström 2006). Using assignment tests, Reusch (2002) found rafting of seed-bearing shoots 30 to $54 \mathrm{~km}$ away from the 
source and IBD estimates of 100 to $150 \mathrm{~km}$ have been documented along the Wadden Sea coast (Olsen et al. 2004, Ferber et al. 2008).

However, despite the critical role of dispersal (Kendrick et al. 2012), meadows within fjords (e.g. Balsfjord) are likely to be more demographically isolated than gene flow or IBD (Fig. 3) suggest. For example, Kobbevågen (Balsfjord) is highly isolated, situated in an inlet in which local current flow probably induces entrainment. Isolation also is likely at the innermost portion of a fjord such as the Sørkjosen sites (Balsfjord) and Elvelund (Sagfjord). Other meadows in Balsfjord, however, are connected by current flows and not differentiated. Laksvatn, Skjæret and Storslett are less dense meadows, situated along the fjord edges. Whereas these may be subject to more successful recruitment, dense meadows may effectively be isolated islands (see discussion below), even though gene flow is high. Because we currently know little about actual recruitment and turnover rates of eelgrass in these fjords, it remains unclear how demographically connected particular meadows are. However, the presence of significant genetic substructure and inbreeding suggests considerable meadow isolation. Clarification of actual connectivity remains fundamental to establishing ecological coherence models, an area that is in active development and for which genetic data are highly desirable.

\section{Substructure within meadows - stochastic processes or habitat selection}

Genetic substructure was present within all 3 fjords. At Sørkjosen (Balsfjord), intertidal and subtidal plants (700 m apart and morphologically indistinguishable) were strongly differentiated in all analyses, as were the plants from the Medby sites in Sagfjord (Figs. 1 \& 2) and the 2 Sør-Lenangen sites. Sporadic recruitment and limited dispersal are 2 factors contributing to substructure. Both are affected by shoot density of the meadow, which itself can become a recruitment barrier (Duarte et al. 2006, Neiva et al. 2012). Mosaic patterns of Zostera marina genotypes, attributed to sporadic recruitment and limited dispersal, have been documented in Brittany (Becheler et al. 2010) and Schleswig-Holstein (Hämmerli \& Reusch 2003). Both Medby and Sørkjosen are dense meadows, suggesting that recruitment may be limited. Creation of a large area of distinct substructure requires the opening of large gaps that favor new recruitment, such as destructive (as opposed to normal) waterfowl grazing (Zipperle et al. 2010) or past habitat destruction by an- chors or fishing traps. Although destructive waterfowl grazing could be an explanation applied to the intertidal Medby sites, it is unlikely at the subtidal (2.5 to $5 \mathrm{~m}$ deep at low tide) Sørkjosen-deep site which is too deep. Alternatively, substructure may result from ecotypic differentiation, as fjords and specific habitats within fjords can promote local selection. Although the presence of distinct subgroups within the Sørkjosen and Medby sites suggests that ecotypic differentiation is possible, demonstration of local habitat selection (Stockwell et al. 2003) requires experimental support, which putatively neutral microsatellite loci cannot provide. However, genome scans of common garden and reciprocal transplant experiments have revealed selection between intertidal and subtidal, and depth-associated genotypes of $Z$. marina (Oetjen \& Reusch 2007, Oetjen et al. 2010, Winters et al. 2011), illustrating that ecotypic differentiation is common.

The narrow-leaved Zostera marina var. angustifolia and the wide-leaved $Z$. marina at Kvitberget and Sørkjosen-littoral could not be distinguished by the microsatellite analysis, a conclusion that further supports the results of Becheler et al. (2010) in Brittany and was also reached using chloroplast and nuclear DNA sequences of the 2 morphotypes in Denmark and Orkney (J. A. Coyer unpubl. data). Clearly, ecotypes with respect to leaf width do exist and may be an indication of local selection that cannot be detected with the microsatellite loci used in our study. Furthermore, leaf width is a stable phenotypic characteristic and cannot be attributed to morphological plasticity. Since one of the goals of conservation is to preserve the integrity of gene pools, including infraspecific categories that may have no official taxonomic or legal status (Groom et al. 2006, Allendorf \& Luikart 2007), it is important to protect areas sufficiently large to capture as much of the full range of diversity (genetic and/or morphological) as possible. Thus, cryptic infraspecific taxa that are morphologically indistinguishable from one another, as well as infraspecific taxa that are morphologically distinguishable (e.g. Z. marina var. angustifolia) can be protected within a management area, without assignment of any special legal status.

\section{Eelgrass and the larger eco-evo conservation context}

The widely held notion that populations in the high latitudes and/or at the extreme northern edge of a species' distribution are genetically depauperate and 'struggling' is unsubstantiated, as our study showed that meadows of Zostera marina along northern Nor- 
wegian fjords have a higher than expected level of regional allelic diversity, are genotypically/clonally diverse, display some evidence of local ecotypes and were generally healthy in appearance. The importance of high genotypic diversity for community function is well-documented for $Z$. marina and can lead to enhanced growth rates and competitive ability (Hämmerli \& Reusch 2003); greater biodiversity of the associated biota (Reusch et al. 2005); greater biomass production following grazing by geese (Hughes \& Stachowicz 2004); greater shoot density (reflective of habitat quality) and biomass of epiphytic algae (as a measure of food resource availability) (Hughes \& Stachowicz 2009a,b); enhanced 'high disturbance' response, leading to better resilience (Hughes \& Stachowicz 2011); and increased restoration success (Reynolds et al. 2012). In addition, all of the aforementioned outcomes of higher genotypic diversity translate to enhanced ecosystem services (Kenworthy et al. 2006, Reynolds et al. 2012), of which habitat nursery function is one of the most important (Heck et al. 2003). High abundances of juvenile cod are associated with eelgrass meadows along the southern coast of Norway (Fjøsne \& Gjøsæter 1996) and eelgrass in the Balsfjord meadows provide spawning ground for herring and capelin, as well as grazing areas for numerous waterfowl (Strann et al. 2011, www.naturbase.no). Thus, loss of eelgrass is of general concern.

While the Norwegian mapping project is discovering many meadows in places not previously investigated, temporal comparisons in areas that were mapped 100 years ago (and/or after the wasting disease of the 1930s) indicate as much as a $36 \%$ reduction in the areal extent of meadows (N. M. Jørgensen $\& \mathrm{~T}$. Bekkby unpubl. data). Some of the losses are directly attributable to landfill operations, whereas others are thought to be the result of agricultural runoff from farms along the fjords. Threats to eelgrass sustainability can be ameliorated through greater public awareness. This is especially important because more extensive fjord usage and consequent pressure on eelgrass ecosystem services can be expected in the coming decades. It is also increasingly evident that individual meadows must be protected as much as is reasonably possible, as our study suggests that demographic isolation may be present even in the presence of gene flow. This was also found in other studies of Zostera marina meadows in close proximity to one another (Muñiz-Salazar et al. 2006, Baja California peninsula; Coyer et al. 2008, California Channel Islands; Wyllie-Echeverria et al. 2010, San Juan Archipelago; Ort et al. 2012, San Francisco Bay). Thus, large and dense meadows such as those at Sørkjosen and Medby, as well as smaller and sparser inter- and subtidal meadows, are of equal importance, because destroyed meadows may not reestablish.

In conclusion, our ultimate ability to effectively evaluate and manage seagrass ecosystems will depend upon a better understanding of how genetic diversity and population structure affect ecological function and landscape coherence in real time. Genetic surveys add an important evolutionary dimension towards the conservation of genetic-level diversity, an explicit goal of the International Convention on Biological Diversity (Laikre et al. 2010).

Acknowledgements. We thank Captain A. Hermansen and the crew of the RV 'Guttorm' for fieldwork assistance and P. Palsbøll for help with the data analyses. This research was supported by a grant allocated to J.L.O. from the Fram Centre flagship 'Effects of climate change on the sea and coastal ecology in the north' (2011). Free Access charges were paid for by COST Action 0906-Seagrass Productivity: from Genes to Ecosystem Management.

\section{LITERATURE CITED}

Allendorf FW, Luikart G (2007) Conservation and the genetics of populations. Blackwell, London

Arnaud-Haond S, Belkhir K (2007) GenClone: a computer program to analyse genotypic data, test for clonality and describe spatial clonal organization. Mol Ecol Notes 7: 15-17

Becheler R, Diekmann O, Hilyl C, Moalic Y, Arnaud-Haond S (2010) The concept of population in clonal organisms: mosaics of temporally colonized patches are forming highly diverse meadows of Zostera marina in Brittany. Mol Ecol 19:2394-2407

> Bekkby T, Rinde E, Erikstad L, Bakkestuen V and others (2008) Spatial probability modelling of eelgrass Zostera marina L. distribution on the west coast of Norway. ICES J Mar Sci 65:1093-1101

Bekkby T, Bodvin T, Bøe R, Moy FE, Olsen H, Rinde E (2011) National program for mapping and monitoring of marine biodiversity in Norway. Final report for the period 2007-2010. Norwegian Institute for Water Research Rep 6105, NIVA, Oslo (in Norwegian with English Abstract)

Belkhir K, Borsa P, Goudet J, Chikhi L, Bonhomme F (2001) GENETIX, logiciel sous Windows ${ }^{\mathrm{TM}}$ pour la genetique des populations. Laboratoire Genome et Populations, Montpellier. http://kimura.univ-montp2.fr/genetix/

Billingham MR, Reusch TBH, Alberto F, Serrão EA (2003) Is asexual reproduction more important at geographical limits? A genetic study of the seagrass Zostera marina in the Ria Formosa, Portugal. Mar Ecol Prog Ser 265:77-83

Bradwell T, Stoker MS, Golledge NR, Wilson CK and others (2008) The northern sector of the last British Ice Sheet: maximum extent and demise. Earth Sci Rev 88:207-226

Cavalli-Sforza L, Edwards AWF (1967) Phylogenetic analysis: models and estimation procedures. Am J Hum Genet 19:233-257

> Costanza R, d'Arge R, de Groot R, Farber S and others (1997) The value of the world's ecosystem services and natural capital. Nature 387:253-260 
Coyer JA, Miller KA, Engle JM, Veldsink J, Cabello-Pasini A, Stam WT, Olsen JL (2008) Eelgrass meadows in the California Channel Islands and adjacent coast reveal a mosaic of two species, evidence for introgression and variable clonality. Ann Bot 101:73-87

Coyer JA, Hoarau G, Beszerti B, Pearson G, Olsen JL (2009) Expressed sequence tag derived polymorphic SSR markers for Fucus serratus and amplification in other species of Fucus. Mol Ecol Resour 9:168-170

> Coyer JA, Hoarau G, van Schaik J, Luijckx P, Olsen JL (2011) Trans-Pacific and trans-Arctic pathways of the intertidal macroalgal Fucus distichus reveal multiple glacial refugia and colonisations from the North Pacific to the North Atlantic. J Biogeogr 38:756-777

> Diekmann OE, Serrão E (2012) Range-edge genetic diversity: locally poor extant southern patches maintain a regionally diverse hotspot in the seagrass Zostera marina. Mol Ecol 21:1647-1657

> Duarte CM, Martínez C, Barrón C (2002) Biomass, production and rhizome growth near the northern limit of seagrass Zostera marina distribution. Aquat Bot 72:183-189

Duarte CM, Fourgrean JW, Krause-Jensen D, Olesen B (2006) Dynamics of seagrass stability and change. In: Larkum AWD, Orth RJ, Duarte CM (eds) Seagrasses: biology, ecology and conservation. Springer, Dordrecht, p 271-294

Earl DA, vonHoldt BM (2012) STRUCTURE HARVESTER: a website and program for visualizing STRUCTURE output and implementing the Evanno method. Conserv Genet Resour 4:359-361

Evanno G, Regnaut S, Goudet J (2005) Detecting the number of clusters of individuals using the software STRUCTURE: a simulation study. Mol Ecol 14:2611-2620

Excoffier L, Laval G, Scheider S (2005) Arlequin ver. 3.0: an integrated software package for population genetics data analysis. Evol Bioinform Online 1:47-50

Felsenstein J (1994) PHYLIP (phylogeny inference package). Department of Genetics, University of Washington, Seattle, WA. http://evolution.genetics.washington.edu/ phylip.html

Ferber S, Stam WT, Olsen J (2008) Genetic diversity and connectivity remain high in eelgrass Zostera marina populations in the Wadden Sea, despite major impacts. Mar Ecol Prog Ser 372:87-96

Fjøsne K, Gjøsæter J (1996) Dietary composition and the potential food competition between 0-group cod (Gadus morhua L.) and some other fish species in the littoral zone. ICES J Mar Sci 53:757-770

Fredriksen S, Christie H (2003) Zostera marina (Angiospermae) and Fucus serratus (Phaeophyceae) as habitat for flora and fauna - seasonal and local variation. In: Chapman ARO, Anderson RJ, Vreeland VJ, Davison IR (eds) Proc 17th Int Seaweed Symp, Cape Town 2001. Oxford University Press, Oxford, p 357-364

Fredriksen S, Christie H, Böstrom C (2004) Deterioration of eelgrass (Zostera marina L.) through destructive grazing by the gastropod Rissoa membranacea (J. Adams). Sarsia 89:218-222

> Fredriksen S, Christie H, Saethre BA (2005) Species richness in macroalgae and macrofauna assemblages on Fucus serratus L. (Phaeophyceae) and Zostera marina L. (Angiospermae) in Skagerrak, Norway. Mar Biol Res 1:2-19

Fredriksen S, De Backer A, Boström C, Christie H (2010) The infauna from Zostera marina L. meadows in Norway. Differences in vegetated and unvegetated areas. Mar Biol Resour 6:189-200
Gaggiotti OE (2010) Preface to the special issue: advances in the analysis of spatial genetic data. Mol Ecol Res 10: 757-759

Groom MJ, Meffe GK, Carroll CR (2006) Principles of conservation biology, 3rd edn. Sinauer Associates, Sunderland, MA

Hämmerli A, Reusch TBH (2003) Genetic neighbourhood of clone structures in eelgrass meadows quantified by spatial autocorrelation of microsatellite markers. Heredity 91:448-455

Heck KL Jr, Hays G, Orth RJ (2003) Critical evaluation of the nursery role hypothesis for seagrass meadows. Mar Ecol Prog Ser 253:123-136

> Hewitt GM (2000) The genetic legacy of the Quaternary ice ages. Nature 405:907-913

Hewitt GM (2004) Genetic consequences of climatic oscillations in the Quaternary. Philos Trans R Soc Lond B Biol Sci 359:183-196

Hoarau G, Coyer JA, Stam WT, Olsen JL (2007) A fast and inexpensive DNA extraction/purification method for brown macroalgae. Mol Ecol Notes 7:191-193

> Hughes AR, Stachowicz JJ (2004) Genetic diversity enhances the resistance of a seagrass ecosystem to disturbance. Proc Natl Acad Sci USA 101:8998-9002

> Hughes AR, Stachowicz JJ (2009a) Morphological and physiological variation among seagrass (Zostera marina) genotypes. Oecologia 159:725-733

> Hughes AR, Stachowicz JJ (2009b) Ecological impacts of genotypic diversity in the clonal seagrass Zostera marina. Ecology 90:1412-1419

Hughes AR, Stachowicz JJ (2011) Seagrass genotypic diversity increases disturbance response via complementarity and dominance. J Ecol 99:445-453

Ibrahim KM, Nichols RA, Hewitt GM (1996) Spatial pattern of genetic variation generated by different forms of dispersal during range expansion. Heredity 77 : 282-291

> Jensen JL, Bohonak AJ, Kelley ST (2005) Isolation by distance, web service. BMC Genetics 6:13. v.3.23, http:// ibdws.sdsu.edu/

> Joseph V, Locke A, Godin JG (2006) Spatial distribution of fishes and decapods in eelgrass (Zostera marina L.) and sandy habitats of a New Brunswick estuary, eastern Canada. Aquat Ecol 40:111-123

Källström B (2006) Stress as an evolutionary force: causes, consequences and adaptations to extrinsic and intrinsic stresses. PhD thesis, University of Gothenburg

> Kendrick GA, Waycott M, Carruthers TJB, Cambridge ML and others (2012) The central role of dispersal in the maintenance and persistence of seagrass populations. Bioscience 62:56-65

Kenworthy WJ, Wyllie-Escheverria S, Coles RG, Pergent G, Pergent-Martini C (2006) Seagrass conservation biology: an interdisciplinary science for protection of the seagrass biome. In: Larkum WD, Orth RJ, Duarte CM (eds) Seagrasses: biology, ecology and conservation. Springer, Dordrecht, p 595-623

Laikre L, Allendorf FW, Aroner LC, Baker CS and others (2010) Neglect of genetic diversity in implementation of the Convention on Biological Diversity. Conserv Biol 24: 86-88

Lid J, Lid DT (1994) Lids flora. 6. utgave ved R. Elven. Det Norske Samlaget, Oslo

Lowe WH, Allendorf FW (2010) What can genetics tell us about population connectivity? Mol Ecol 19:3038-3051 
Maggs CA, Castilho R, Foltz D, Henzler C and others (2008) Evaluating signatures of glacial refugia for North Atlantic marine organisms. Ecology 89:S108-S122

Manly BFJ (1994) Multivariate statistical methods: a primer, 2nd edn. Chapman \& Hall, New York, NY

Moran MD (2003) Arguments for rejecting the sequential Bonferroni in ecological studies. Oikos 100:403-405

> Muñiz-Salazar R, Talbot SL, Sage GK, Ward DH, CabelloPasini A (2006) Genetic structure of eelgrass Zostera marina meadows in an embayment with restricted water flow. Mar Ecol Prog Ser 309:107-116

Neiva J, Pearson GA, Valero M, Serrão EA (2012) Fine-scale genetic breaks driven by historical range dynamics and ongoing density-barrier effects in the estuarine seaweed Fucus ceranoides L. BMC Evol Biol 12:78-86

- Nilsson-Jacobi M, Jonsson PR (2011) Optimal networks of nature reserves can be found through eigenvalue perturbation theory of the connectivity matrix. Ecol Appl 21: 1861-1870

> Nilsson-Jacobi M, Jonsson PR (2012) Optimal selection of marine protected areas based on connectivity and habitat quality. Ecol Model 240:105-112

Norman JM (1900) Norges arktiske flora. Del I. Speciel plantetopografi. Oscar Andersens bogtrykkeri, i kommisjon hos H. Aschehoug, University of California, Berkeley, CA

> Oetjen K, Reusch TBH (2007) Genome scans detect consistent divergent selection among subtidal vs. intertidal populations of the marine angiosperm Zostera marina. Mol Ecol 16:5156-5167

Oetjen K, Ferber S, Dankert I, Reusch TBH (2010) New evidence for habitat-specific selection in Wadden Sea Zostera marina populations revealed by genome scanning using SNP and microsatellite markers. Mar Biol 157: 81-89

Olsen JL, Stam WT, Coyer JA, Reusch TBH and others (2004) North Atlantic phylogeography and large-scale population differentiation of the seagrass Zostera marina L. Mol Ecol 13:1923-1941

Ort BS, Cohen CS, Boyer KE, Wyllie-Echeverria S (2012) Population structure and genetic diversity among eelgrass (Zostera marina) beds and depths in San Francisco Bay. J Hered 103:533-546.

> Orth RJ, Carruthers TJB, Dennison WC, Duarte CM and others (2006) A global crisis for seagrass ecosystems. Bioscience 56:987-996

Pennisi E (2012) Eco-evo effects up and down the food chain. Science 337:906-907

> Petit RJ, Aguinagalde I, De Beaulieu JL, Bittkau C and others (2003) Glacial refugia: hotspots but not melting pots of genetic diversity. Science 300:1563-1565

> Pritchard JK, Stephens P, Donnelly P (2000) Inference of population structure using multilocus genotype data. Genetics 155:945-959

Procaccini G, Olsen JL, Reusch TBH (2007) Contribution of genetics and genomics to seagrass biology and conservation. J Exp Mar Biol Ecol 350:234-259

Reusch TBH (2000) Five microsatellite loci in eelgrass Zostera marina and a test of cross-species amplification in Z. noltii and Z. japonica. Mol Ecol 9:371-373

$>$ Reusch TBH (2001) Fitness-consequences of geitonogamous selfing in a clonal marine angiosperm (Zostera marina). J Evol Biol 14:129-138.

Reusch TBH (2002) Microsatellites reveal high population connectivity in eelgrass (Zostera marina) in two contrasting coastal areas. Limnol Oceanogr 47:78-85
Reusch TBH, Boström C (2011) Widespread genetic mosaicism in the marine angiosperm Zostera marina is correlated with clonal reproduction. Evol Ecol 25:899-913

Reusch TBH, Chapman ARO, Gröger JP (1994) Blue mussels Mytilus edulis do not interfere with eelgrass Zostera marina but fertilize shoot growth through biodeposition. Mar Ecol Prog Ser 108:265-282

> Reusch TBH, Boström C, Stam WT, Olsen JL (1999) An ancient eelgrass clone in the Baltic Sea. Mar Ecol Prog Ser 183:301-304

Reusch TBH, Stam WT, Olsen JL (2000) A microsatellitebased estimation of clonal diversity and population subdivision in Zostera marina, a marine flowering plant. Mol Ecol 9:127-140

> Reusch TBH, Ehlers A, Hämmerli A, Worm B (2005) Ecosystem recovery after climatic extremes enhanced by genotypic diversity. Proc Natl Acad Sci USA 102:2826-2831

> Reynolds LK, McGlathery KJ, Waycott M (2012) Genetic diversity enhances restoration success by augmenting ecosystem services. PLoS ONE 7:e38397

Rousset F (1997) Genetic differentiation and estimation of gene flow from $F$-statistics under isolation by distance. Genetics 145:1219-1228

Slatkin M (1993) Isolation by distance in equlibrium and non-equlibrium populations. Evolution 47:264-279

Slatkin M, Excoffier L (1996) Testing for linkage disequilibrium in genotypic data using the EM algorithm. Heredity 76:377-383

Spielman D, Brook BW, Frankham R (2004) Most species are not driven to extinction before genetic factors impact them. Proc Natl Acad Sci USA 101:15261-15264

Stockwell CA, Hendry AP, Kinnison MT (2003) Contemporary evolution meets conservation biology. Trends Ecol Evol 18:94-101

Stonehouse B (1989) Polar ecology. Blackie, London

Strann KB, Riser W, Bakken V (2011) Balsfjord våtmarksystem [Balsfjord wetland system]. Arctic Research and Consulting, Livonia Print, Riga

Waycott M, Procaccini G, Les D, Reusch TBH (2006). Seagrass evolution, ecology and conservation: a genetic perspective. In: Larkum AWD, Orth RJ, Duarte CM (eds) Seagrasses: biology, ecology and conservation. Springer, Dordrecht, p 25-50

Waycott M, Duarte C, Carruthers T, Orth RJ and others (2009) Accelerating loss of seagrasses across the globe threatens coastal ecosystems. Proc Natl Acad Sci USA 106:12377-12381

- Weir BS, Cockerham CC (1984) Estimating F-statistics for the analysis of population structure. Evolution 38:1358-1370

> Winters G, Nelle P, Fricke B, Rauch G, Reusch TBH (2011) Effects of a simulated heat wave on photophysiology and gene expression of high- and low-latitude populations of Zostera marina. Mar Ecol Prog Ser 435:83-95

Wright S (1943) Isolation by distance. Genetics 28:114-138 Wyllie-Echeverria S, Talbot SL, Rearick JR (2010) Genetic structure and diversity of Zostera marina (eelgrass) in the San Juan Archipelago, Washington, USA. Estuaries Coasts 33:811-827

Zipperle AM, Coyer JA, Reise K, Stam WT, Olsen JL (2009) Evidence for persistent seed banks in dwarf eelgrass Zostera noltii in the German Wadden Sea. Mar Ecol Prog Ser 380:73-80

Zipperle AM, Coyer JA, Reise K, Stam WT, Olsen JL (2010) Waterfowl grazing in autumn enhances spring seedling recruitment of intertidal Zostera noltii. Aquat Bot 93:202-205 